\title{
Embryo Culture Media Influence on Live Birth Rate and Birthweight after IVF/ICSI: A Systematic Review Comparing Vitrolife G5 Media to Other Common Culture Media
}

\author{
Lena Bick ${ }^{1}$, Anja Schulz Nielsen ${ }^{1}$, Ulla Breth Knudsen ${ }^{1,2}$ \\ ${ }^{1}$ Faculty of Health, Aarhus University, Nordre Ringgade 1, 8000 Aarhus, Denmark \\ 2Department of Obstetrics \& Gynecology, Regional Hospital Horsens, Sundvej 30, 8700 Horsens, Denmark
}

\begin{abstract}
Previous studies have indicated that culture media vary in efficiency and outcomes, such as live birth rate, birthweight and embryo quality. Does Vitrolife G5 series culture media result in higher live birth rates and birthweight compared to other common culture media? This study is a systematic review based on the PRISMA criteria. Relevant search terms, mesh terms (PubMed and Cochrane) and Emtree terms (Embase) were identified. We searched the literature using PubMed, Embase and Cochrane, on November 10, 2019. The inclusion criteria involved published articles in English comparing Vitrolife G5 to other common culture media. We included randomized controlled trials (RCTs) and cohort studies. The quality of the studies was assessed using the Cochrane Risk of Bias tool 2.0 and the Newcastle-Ottawa Scale. Primary outcomes were live birth rate and birthweight. Secondary outcomes were fertilization rate, implantation rate, biochemical pregnancy rate, clinical pregnancy rate, miscarriage rate, multiple pregnancies and congenital malformations. Of 187 articles screened, 11 studies fulfilled the inclusion criteria: Five RCTs and six retrospective cohort studies. Only one study reported live birth rate, showing a non-significantly higher live birth rate for Vitrolife G5 media. Birthweight had equivocal results with three of six studies, showing significantly lower (2)/higher (1) birthweights, whereas the others were non-significant. Overall, there were no significant differences concerning secondary outcomes. The results are equivocal, and we need more studies to evaluate culture media and their effect on short- and longterm health.
\end{abstract}

Keywords: Culture Media, Fertilization in Vitro, Reproductive Techniques, Assisted, Birth Weight, Pregnancy Rate, Live Birth

\section{INTRODUCTION}

In in vitro fertilization (IVF) and intracytoplasmic sperm injection (ICSI), the fertilized embryos are cultivated in culture media to choose the best embryo to transfer to the uterus either at cleavage stage or as a blastocyst. To make this possible, the oocytes and embryos are transferred to one or several culture media that support the early development of the embryos. These media have evolved from simple culture media based on blood serum to complex media containing a variety of different substances such as amino acids, human albumin, vitamins, antibiotics and growth factors (Chronopoulou \& Harper, 2015).

While the culture media of the early years were homemade in fertilization clinics, fewer, but more specialized companies now commercially produce them. This has added economic interests, resulting in lack of transparency regarding media composition, but it has also led to increased quality and more quality control (Chronopoulou \& Harper, 2015). Culture media can be divided into sequential media such as the G5 series (Vitrolife), where different culture media are used throughout the embryo development; or single media, such as GL BLAST sole medium (Ingamed), where only one single medium is used for the whole period, until the blastocyst stage.

Previous studies have indicated that different culture media vary in their efficiency and outcomes, such as live birth rate, birthweight and embryo quality (Youssef et al., 2015; Mantikou et al., 2013). Studies suggest that culture media influence gene expression and epigenetics in animals and humans, which might affect the long-term health of the children (Schwarzer et al., 2012; Kleijkers et al., 2015).

The number of infertile women submitted to IVF is increasing. Therefore, we undertook this study to compare the common culture media G5 series (Vitrolife, Sweden) to other common culture media, with the prime focus on live birth rates and birthweight.

\section{MATERIALS AND METHODS}

We used the PRISMA criteria in this review. The study is registered in Prospero (CRD42020153820). Two of the review team members ( $L$ Bick and $A S$ Nielsen) did data collection, data extraction and the assessment of the studies independently. Discussion or a third person ( $U$ B Knudsen) solved disagreements.

\section{Outcomes}

The primary outcomes were live birth rate and birthweight. Live birth rate was defined as the proportion of women giving birth to at least one child born alive, independent of gestational age. Birthweight was defined as the mean birthweight of the babies measured in grams.

Secondary outcomes were fertilization rate, implantation rate, biochemical pregnancy rate, clinical pregnancy rate, miscarriage rate, multiple pregnancy rate and congenital malformations. Most definitions were based on Kleijkers et al. (2016), but may vary slightly among the different studies. The fertilization rate was defined as the percentage of fertilized oocytes (containing two pronuclei) among the number of mature oocytes (metaphase II) inseminated or injected. The implantation rate was defined as the number of gestational sacs identified by transvaginal ultrasound after six to eight weeks of gestation, divided by the number of embryos transferred. The biochemical pregnancy rate was defined as the percentage of women having at least one serum beta-hCG test of at least $50 \mathrm{UI} / \mathrm{l}$ two weeks after embryo transfer. The clinical pregnancy rate was defined as the percentage of women with a gestational sac and a fetal heartbeat, identified by transvaginal ultrasound examination at six to eight weeks of gestation. A miscarriage was determined as a biochemical pregnancy not resulting in a live birth. The multiple pregnancy rate was defined as the percentage of live births resulting in more than one child. Congenital malformations were divided into minor and major malformations. Major 
malformations were defined as malformations causing functional impairment or requiring surgical correction, and the remaining malformations were considered minor.

\section{Data Collection}

We ran a systematic search on PubMed, Embase and the Cochrane Library on November 10, 2019.

The inclusion criteria were published articles in English on clinical trials containing well-defined data on at least one of the primary and/or secondary outcomes comparing Vitrolife $\mathrm{G} 5$ series culture media with other common culture media in humans. Both randomized controlled trials (RCTs) and cohort studies were included. Initially, there was no time limit on the search, but since Vitrolife G5 series was introduced in 2007, all articles from before 2007 were later excluded.

The research keywords was set up using the PICO model and divided into four search blocks. We used relevant search terms, mesh terms (PubMed and Cochrane) and Emtree terms (Embase). The four search blocks were used to run a combined search. The PICO table, search terms and examples of search queries can be found in the Supplements section of this review.

The data collection is illustrated on the PRISMA flow diagram (Figure 1). The search in the three databases resulted in 44 results in PubMed, 63 results in Cochrane and 112 results in Embase. This yielded 219 results.
We removed the duplicates, resulting in 186 hits. We read the abstracts from the 186 results. When information was missing in the abstracts, for instance, whether the culture media was part of the Vitrolife G5 series, we searched for information in the full article. Of the 186 studies, 176 were excluded because either they did not contain any data comparing between Vitrolife $\mathrm{G} 5$ series and other culture media, they were animal studies, reviews, conference abstracts, or they were published before the G5 series was introduced in 2007. The participants in one study (Kleijkers et al., 2015) were enclosed in a larger study (Kleijkers et al., 2016), and therefore, only Kleijkers et al. (2016) was included. The reviews and their references were searched to find any data comparing G5 series media to other culture media.

We ran a Scopus citation search on the 10 remaining studies. The titles and abstracts of articles citing the 10 studies were searched to identify other relevant studies in which the systematic search might have been missing. One additional study was found, resulting in 11 studies to be included in this review.

Data extraction and assessment of included studies

We read the included articles and extracted the data regarding primary and secondary outcomes. When available, we collected additional data, such as the type of G5 product, whether the study was an IVF/ICSI study, and whether the study used fresh or frozen embryos.

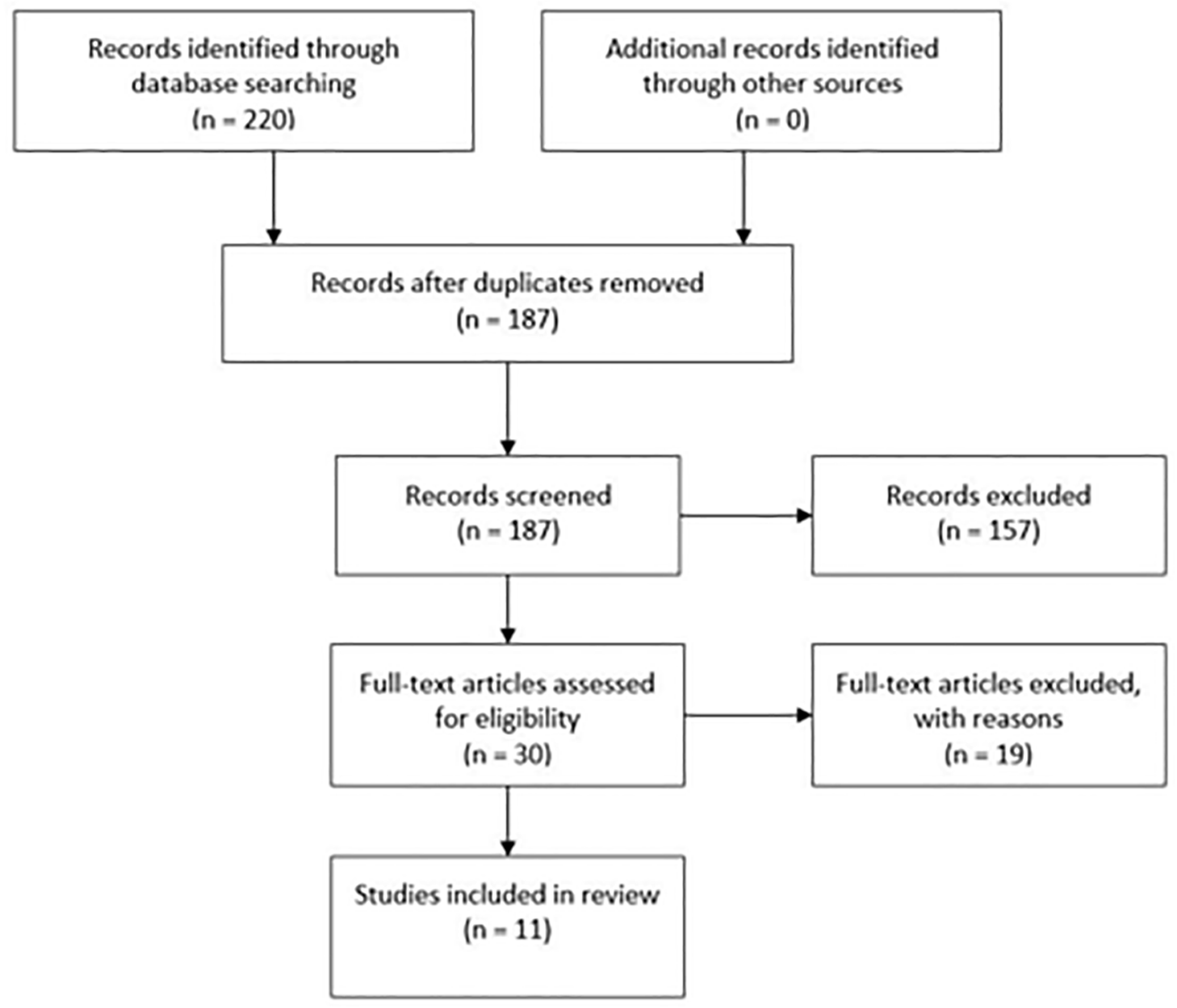

Figure 1. PRISMA flow chart. 
RCTs were assessed by Version 2 of the Cochrane riskof-bias tool for randomized trials (RoB 2), shown in Table 1. The Newcastle-Ottawa Scale (NOS), shown in Table 3, assessed cohort studies. After the individual assessment was completed, a final assessment was found, and disagreements were solved by discussion or by a third person.

\section{RESULTS}

The data collection is illustrated on the flow diagram (Figure 1 ). Of the 219 articles, only 11 studies qualified to be included in this review.

In Table 1, you find the RoB 2 assessment of the RCTs, and Table 2 shows additional information about the studies. Table 3 shows the NOS assessment of the retrospective cohort studies; and Table 4 shows additional information about the studies. Table 5 shows an overview of the 11 studies regarding the type of culture media, whether the study included IVF or ICSI or both, and which of the outcomes each study included. Table 6 shows the results of the primary outcomes, and Table 7 shows the results of the secondary outcomes.

\section{Primary outcomes}

\section{Live birth rate}

Kleijkers et al. (2016) found in an RCT that G5 culture media tended to have a slightly higher live birth rate than the HTF culture media, but the difference was nonsignificant (Table 6 ). None of the other studies report on live birth rate.

\section{Birthweight}

Two studies out of six found a significantly lower birthweight for G5 media, whereas one study found a significant higher birthweight for G5 (Table 6). Kleijkers et al. (2016) found in an RCT that G5 had a $158 \mathrm{~g}$ lower birthweight compared to the HTF culture media; and Hassani et al. (2013) found in an RCT a $370 \mathrm{~g}$ lower birthweight comparing G5 to ISM1. Eskild et al. (2013) found in a retrospective study a significant higher birthweight comparing G5 to Universal IVF medium and ISM1, where G5 was found to have a $92.4 \mathrm{~g}$ higher birthweight compared to ISM1.

Three of the retrospective cohort studies did not find any differences (Gu et al., 2016 - Quinn's media, De Vos et al., 2015 - Medicult and Lin et al., 2015 - Global culture media), even though all three studies included more than one thousand embryos.

Kleijkers et al. (2016) included both fresh and frozen embryos in their analysis with total numbers only. De Vos et al., 2015 included both fresh and frozen embryos, and had separate results. The other studies included fresh embryos only.

\section{Secondary outcomes}

\section{Fertilization rate}

One RCT study reported that G5 had a significantly lower fertilization rate compared to the HTF culture media (Kleijkers et al., 2016), and one RCT study reported that G5 had a significantly higher fertilization rate compared to Universal IVF Medium (Hambiliki et al., 2011) (Table 7). Two RCTs and a retrospective cohort study reported no differences comparing G5 to Cook Sequential Medium, GV Blast Sole and SAGE 1-STEP (Zhang et al., Ceschin et al., 2016; Lopez-Pelayo et al., 2018).

\section{Implantation rate}

One RCT found a significantly higher implantation rate for G5 compared to the HTF culture media (Kleijkers et al., 2016) (Table 7).

Three RCTs and a retrospective cohort study found no difference comparing G5 to Cook Sequential Medium, ISM1, Universal IVF Medium and SAGE 1-STEP (Zhang et al., 2016 Hassani et al., 2013; Hambiliki et al., 2011 LopezPelayo et al., 2018).

\section{Biochemical pregnancy rate}

In three RCTs, no difference in biochemical pregnancy rate was found comparing G5 to HTF, GV Blast Sole and Universal IVF Medium (Kleijkers et al., 2016; Ceschin et al., 2016; Hambiliki et al., 2011) (Table 7).

\section{Clinical pregnancy rate}

In an RCT and in a retrospective cohort study, a significantly higher clinical pregnancy rate was found comparing G5 to HTF and Global (Kleijkers et al., 2016; Lin et al., 2015) (Table 7). Five studies including three RCTs and two retrospective cohort studies found no difference comparing G5 to Cook Sequential Media, ISM1, Universal IVF Medium, SAGE 1-STEP medium, Global, and Quinn's advantage medium (Zhang et al., 2016; Hassani et al., 2013; Hambiliki et al., 2011; Lopez-Pelayo et al., 2018; Lin et al., 2013).

Table 1. Assessment of RCTs - Version 2 of the Cochrane risk-of-bias tool for randomized trials (RoB 2).

\begin{tabular}{|l|l|l|l|l|l|l|l|}
\hline Reference & Domain 1 & Domain 2 & Domain 3 & Domain 4 & Domain 5 & Overall Risk & Comments \\
\hline Kleijkers et al. 2016 & & & & & & & \\
\hline Zhang et al. 2016 & & & & & & & \\
\hline Ceschin et al. 2016 & & & & & & & \\
\hline Hassani et al. 2013 & & & & & & $\begin{array}{l}\text { No true } \\
\text { randomization } \\
\text { (alternate } \\
\text { allocation) }\end{array}$ \\
\hline Hambiliki et al. 2011 & & & & & & & \\
\hline
\end{tabular}

Domain 1: Risk of bias arising from the randomization process

Domain 2: Risk of bias due to deviations from the intended interventions (effect of assignment to intervention)

Domain 3: Missing outcome data

Domain 4: Risk of bias in measurement of the outcome

Domain 5: Risk of bias in selection of the reported result

Risk of bias: green=low risk, yellow=some concerns, red=high risk 
Table 2. RCTs - Table with additional information and comments. In the top the women were randomized, in the lower two studies the oocytes were randomized.

\begin{tabular}{|c|c|c|c|c|}
\hline Reference & $\begin{array}{l}\text { Country/year } \\
\text { Multicenter/single- } \\
\text { center }\end{array}$ & $\begin{array}{l}\text { Randomization of } \\
\text { women/oocytes }\end{array}$ & $\begin{array}{l}\text { Number of } \\
\text { participants }\end{array}$ & Comments \\
\hline Kleijkers et al. 2016 & $\begin{array}{l}\text { The Netherlands, } \\
2016 \text { Multicenter }\end{array}$ & $\begin{array}{l}\text { Women were } \\
\text { randomized by a } \\
\text { computer program }\end{array}$ & $\begin{array}{l}836 \text { women, } \\
\text { birthweight data from } \\
360 \text { children }\end{array}$ & $\begin{array}{l}\text { Detailed description } \\
\text { of methods used. } \\
\text { Many participants. } \\
\text { Blinding of couples, } \\
\text { gynecologists, fertility } \\
\text { doctors, outcome } \\
\text { examiners. Intention } \\
\text { to treat. Good } \\
\text { description of handling } \\
\text { dropouts. Power } \\
\text { calculation included. }\end{array}$ \\
\hline Ceschin et al. 2016 & $\begin{array}{l}\text { Brazil, } 2016 \text { Single- } \\
\text { center }\end{array}$ & $\begin{array}{l}\text { Women were } \\
\text { randomly divided } \\
\text { into two groups (not } \\
\text { described in detail) }\end{array}$ & $\begin{array}{l}60 \text { women, } \\
311 \text { mature oocytes } \\
\text { for ICSI }\end{array}$ & $\begin{array}{l}\text { Few participants. } \\
\text { Acceptable description } \\
\text { of methods, but short } \\
\text { and not very detailed. }\end{array}$ \\
\hline Hassani et al. 2013 & $\begin{array}{l}\text { Iran, } 2013 \text { Single- } \\
\text { center? }\end{array}$ & $\begin{array}{l}\text { Women were } \\
\text { randomized before } \\
\text { oocyte pick up } \\
\text { according to a } \\
\text { randomization list } \\
\text { based on sequential } \\
\text { numbers in sealed } \\
\text { envelopes }\end{array}$ & 538 women & $\begin{array}{l}\text { Many participants. } \\
\text { Good description } \\
\text { of methods. Clear } \\
\text { inclusion criteria of } \\
\text { the women. }\end{array}$ \\
\hline Zhang et al.,2016 & $\begin{array}{l}\text { China, } 2016 \\
\text { Single-center }\end{array}$ & $\begin{array}{l}\text { Oocytes were } \\
\text { randomized according } \\
\text { to a randomization } \\
\text { table }\end{array}$ & $\begin{array}{l}37 \text { women, } \\
620 \text { oocytes, } \\
64 \text { embryos } \\
\text { transferred }\end{array}$ & $\begin{array}{l}\text { Few participants. } \\
\text { Good description of } \\
\text { methods used. Focus } \\
\text { is on early embryo } \\
\text { cleavage kinetics. }\end{array}$ \\
\hline Hambiliki et al.,2011 & Sweden, 2011 & $\begin{array}{l}\text { Oocytes were divided } \\
\text { to type of culture } \\
\text { media via alternate } \\
\text { allocation }\end{array}$ & $\begin{array}{l}110 \text { women, } \\
1206 \text { oocytes, } \\
108 \text { embryo transfers }\end{array}$ & $\begin{array}{l}\text { Many participants. } \\
\text { Good descriptions } \\
\text { of the methods with } \\
\text { clear inclusion criteria } \\
\text { and definitions of the } \\
\text { outcomes. }\end{array}$ \\
\hline
\end{tabular}

Table 3. Assessment of retrospective cohort studies - Newcastle-Ottawa Scale (NOS)

\begin{tabular}{|c|c|c|c|c|c|}
\hline Reference & Selection & Comparability & $\begin{array}{c}\text { Exposure/ } \\
\text { Outcome }\end{array}$ & $\begin{array}{c}\text { Total } \\
\text { Nos-score }\end{array}$ & Comments \\
\hline Lopéz-Pelayo et al., 2018 & 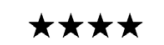 & - & $\star \star \star \star$ & 7 & \\
\hline Gu et al. 2016 & 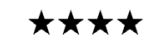 & $\star \star$ & $\star$ & 7 & \\
\hline De Vos et al., 2015 & $\star \star \star \star \star ~$ & $\star \star$ & $\star \star \star$ & 9 & \\
\hline Lin et al., 2015 & $\star \star \star \star \star ~$ & - & $\star \star \star$ & 7 & \\
\hline Lin et al. 2013, & $\star \star \star \star \star ~$ & - & $\star \star \star \star$ & 7 & $\begin{array}{l}\text { CPR only } \\
\text { mentioned } \\
\text { in laboratory } \\
\text { protocol section }\end{array}$ \\
\hline Eskild et al., 2013 & 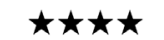 & $\star \star \star$ & $\star \star \star \star$ & 9 & \\
\hline
\end{tabular}

\section{Miscarriage rate}

In two RCTs and in a retrospective cohort study, no difference was found in miscarriage rate comparing $\mathrm{G} 5$ to HTF, ISM1 and SAGE 1-STEP media (Kleijkers et al., 2016; Hassani et al., 2013; Lopez-Pelayo et al., 2018) (Table 7).

\section{Multiple pregnancy rate}

Two RCTs found no difference in multiple pregnancy rates comparing G5 to HTF and ISM1 (Kleijkers et al., 2016, Hassani et al., 2013) (Table 7). The calculation of the percentages for Kleijkers et al. (2016) can be found in the Supplements section of this review. 
Table 4. Retrospective cohort studies - Table with additional information and comments

\begin{tabular}{|c|c|c|c|c|}
\hline Reference & $\begin{array}{l}\text { Country/year } \\
\text { Multicenter/ } \\
\text { single-center }\end{array}$ & $\begin{array}{l}\text { Number of } \\
\text { participants }\end{array}$ & $\begin{array}{l}\text { Selection of participants } \\
\text { and distribution of the } \\
\text { culture media between the } \\
\text { participants }\end{array}$ & Comments \\
\hline $\begin{array}{l}\text { Lopéz-Pelayo } \\
\text { et al., } 2018\end{array}$ & $\begin{array}{l}\text { Spain, } 2018 \\
\text { Single-center }\end{array}$ & 189 women & $\begin{array}{l}189 \text { women undergoing } \\
\text { infertility treatment at the } \\
\text { center in } 2016 . \\
\text { The women were allocated } \\
\text { to one of the culture media } \\
\text { depending on the week of } \\
\text { oocyte retrieval. The type of } \\
\text { media was changed weekly. }\end{array}$ & $\begin{array}{l}\text { A retrospective study with the } \\
\text { fewest participants included in } \\
\text { this review. Good description of } \\
\text { the methods, inclusion criteria } \\
\text { of the groups and definitions of } \\
\text { outcomes. }\end{array}$ \\
\hline Gu et al., 2016 & $\begin{array}{l}\text { China, } 2016 \\
\text { Single-center }\end{array}$ & $\begin{array}{l}2370 \text { singletons. } \\
1755 \text { cases from } \\
\text { fresh embryo } \\
\text { transfer and } \\
615 \text { from frozen } \\
\text { embryo transfer. }\end{array}$ & $\begin{array}{l}\text { Singletons born alive after } \\
28 \text { weeks of gestation who } \\
\text { underwent IVF/ICSI cycles in the } \\
\text { center between June } 2009 \text { and } \\
\text { October } 2012 \text {. } \\
\text { Large proportion of embryos } \\
\text { cultured in SAGE (SAGE 1336, } \\
\text { Vitrolife } 419 \text { ). Gradual change } \\
\text { from most embryos cultured in } \\
\text { SAGE in } 2009 \text { and most embryos } \\
\text { cultured in Vitrolife in } 2012 \text {. }\end{array}$ & $\begin{array}{l}\text { Large group of children. Good } \\
\text { description of the methods. } \\
\text { Good explanations about } \\
\text { birthweight values, which are } \\
\text { the focus of the study. Some } \\
\text { of the values are adjusted for } \\
\text { gestational age and gender. } \\
\text { Pregnancies lost to follow } \\
\text { up were excluded from data } \\
\text { analysis. } \\
\text { There is a risk that some of the } \\
\text { babies are born to the same } \\
\text { woman. }\end{array}$ \\
\hline $\begin{array}{l}\text { De Vos et al., } \\
2015\end{array}$ & $\begin{array}{l}\text { Belgium, } 2015 \\
\text { Single-center }\end{array}$ & $\begin{array}{l}2098 \text { singleton live } \\
\text { births resulting } \\
\text { from only singleton } \\
\text { pregnancies were } \\
\text { included }\end{array}$ & $\begin{array}{l}\text { Data was collected between } \\
\text { April } 2004 \text { and December } 2009 . \\
\text { Medicult was used between } \\
\text { April } 2004 \text { and April } 2009 . \\
\text { Vitrolife G3 was used from } \\
\text { October } 2004 \text { and followed by } \\
\text { G5 from September } 2008 \text { until } \\
\text { December } 2009 \text {. }\end{array}$ & $\begin{array}{l}\text { The study has one table for } \\
\text { birthweight showing the } \\
\text { combined G3/G5 media } \\
\text { compared to Medicult and } \\
\text { a table comparing G3 to } \\
\text { G5 media. Both are non- } \\
\text { significant. }\end{array}$ \\
\hline Lin et al., 2015 & $\begin{array}{l}\text { China, } 2015 \\
\text { Single-center }\end{array}$ & $\begin{array}{l}8686 \text { embryo cy- } \\
\text { cles cultured in G5. } \\
7706 \text { embryo } \\
\text { cycles cultured in } \\
\text { G5 Plus. } \\
7089 \text { embryo } \\
\text { cycles cultured in } \\
\text { Global Medium. }\end{array}$ & $\begin{array}{l}\text { Women who underwent IVF at } \\
\text { the center between } 2011 \text { and } \\
2013 . \\
\text { One type of culture media was } \\
\text { typically used for } 3 \text { days and } \\
\text { then changed to another cul- } \\
\text { ture medium. }\end{array}$ & $\begin{array}{l}\text { Large number of embryos. } \\
\text { Clinical pregnancy rate is the } \\
\text { only relevant outcome since } \\
\text { focus is ectopic pregnancies in } \\
\text { IVF-born children compared } \\
\text { to spontaneous pregnancies. } \\
\text { Not a good description } \\
\text { of the distribution of the } \\
\text { culture media, but it must be } \\
\text { presumed that the embryos } \\
\text { were cultured in only one of the } \\
\text { three culture media, despite } \\
\text { the change in media after } \\
\text { three days. Data distinguishes } \\
\text { between G5 and G5 Plus series. }\end{array}$ \\
\hline Lin et al., 2013 & $\begin{array}{l}\text { China, } 2013 \\
\text { Single-center }\end{array}$ & $\begin{array}{l}1201 \text { singletons } \\
\text { and } 445 \text { sets of } \\
\text { twins }\end{array}$ & $\begin{array}{l}\text { Women who underwent IVF at } \\
\text { the center between } 2008 \text { and } \\
2010 \text {. Singletons and twins born } \\
\text { alive after } 20 \text { weeks of gestation. } \\
\text { No information about the } \\
\text { distribution and time of use of } \\
\text { the different culture media at the } \\
\text { center. }\end{array}$ & $\begin{array}{l}\text { Large group of children. Good } \\
\text { description of the methods. } \\
\text { Multiple linear regression was } \\
\text { performed to find confounding } \\
\text { factors. No explanation about } \\
\text { when the center used the } \\
\text { different culture media. }\end{array}$ \\
\hline $\begin{array}{l}\text { Eskild et al., } \\
2013\end{array}$ & $\begin{array}{l}\text { Norway, } 2013 \\
\text { Single-center }\end{array}$ & 2435 singletons & $\begin{array}{l}\text { Singleton births from IVF/ICSI } \\
\text { born after } 22 \text { weeks of gestation } \\
\text { in the years } 1999-2011 \text {. } \\
\text { The culture media depends on } \\
\text { the year: } \\
1999-2007 \text { Medicult Universal } \\
\text { IVF Medium } \\
2008-2009 \text { Medicult Universal } \\
\text { for fertilization and ISM1 for } \\
\text { embryo culture } \\
2009-2011 \text { Vitrolife G-IVF Plus } \\
\text { for fertilization and G-1 Plus for } \\
\text { embryo culture. }\end{array}$ & $\begin{array}{l}\text { Large group of children and } \\
\text { data from many years. The } \\
\text { focus is comparison between } \\
\text { IVF children and spontaneous } \\
\text { births. The comparison } \\
\text { between the culture media is a } \\
\text { comparison of different years } \\
\text { where laboratory routines may } \\
\text { differ. Linear regression was } \\
\text { performed to find confounding } \\
\text { factors. Adjustments were } \\
\text { made for maternal age, } \\
\text { number of previous deliveries } \\
\text { and gestational age. There is } \\
\text { a risk that some of the babies } \\
\text { are born by the same woman. }\end{array}$ \\
\hline
\end{tabular}




\begin{tabular}{|c|c|c|c|c|c|c|c|c|c|c|c|c|}
\hline Reference & $\begin{array}{l}\text { G5 media, if } \\
\text { specified }\end{array}$ & $\begin{array}{l}\text { Other media, if } \\
\text { specified }\end{array}$ & $\begin{array}{l}\text { IVF/ICSI } \\
\text { and } \\
\text { fresh/ } \\
\text { frozen, if } \\
\text { specified }\end{array}$ & LBR & BW & $\mathbf{F R}$ & IR & BPR & CPR & MR & MP & CA \\
\hline $\begin{array}{l}\text { Kleijkers } \\
\text { et al., } \\
2016\end{array}$ & $\begin{array}{l}\text { G-IVF Plus } \\
\text { G-1 Plus } \\
\text { G-2 Plus }\end{array}$ & HTF (Irvine Scientific) & $\begin{array}{l}\text { IVF/ICSI } \\
\text { Fresh/frozen }\end{array}$ & $x$ & $x$ & $x$ & $x$ & $x$ & $x$ & $x$ & $x$ & $x$ \\
\hline $\begin{array}{l}\text { Zhang } \\
\text { et al. } \\
2016\end{array}$ & $\begin{array}{l}\text { G-IVF Plus } \\
\text { G-1 Plus }\end{array}$ & $\begin{array}{l}\text { Sequential media } \\
\text { (Cook) }\end{array}$ & $\begin{array}{l}\text { IVF } \\
\text { Fresh }\end{array}$ & & & $x$ & $x$ & & $x$ & & & \\
\hline $\begin{array}{l}\text { Ceschin } \\
\text { et al. } \\
2016\end{array}$ & $\begin{array}{l}\text { G-1 Plus } \\
\text { G-2 Plus }\end{array}$ & $\begin{array}{l}\text { GV BLAST sole } \\
\text { medium (Ingamed) }\end{array}$ & $\begin{array}{l}\text { ICSI } \\
\text { Fresh }\end{array}$ & & & & & & & & & \\
\hline $\begin{array}{l}\text { Hassani } \\
\text { et al. } \\
2013\end{array}$ & $\begin{array}{l}\text { G-1 and HAS } \\
\text { EmbryoGlue }\end{array}$ & ISM1 (Medicult) & $\begin{array}{l}\text { IVF/ICSI } \\
\text { Fresh }\end{array}$ & & $x$ & & $x$ & & $x$ & $x$ & $x$ & \\
\hline $\begin{array}{l}\text { Hambiliki } \\
\text { et al. } \\
2011\end{array}$ & $\begin{array}{l}\text { G-IVF Plus } \\
\text { G-1 Plus }\end{array}$ & $\begin{array}{l}\text { Universal IVF } \\
\text { medium/EmbryoAssist } \\
\text { (Medicult) }\end{array}$ & $\begin{array}{l}\text { IVF/ICSI } \\
\text { Fresh? }\end{array}$ & & & $x$ & $x$ & $x$ & $x$ & & & \\
\hline $\begin{array}{l}\text { Lopéz- } \\
\text { Pelayo } \\
\text { et al. } \\
2018\end{array}$ & $\begin{array}{l}\text { G-IVF } \\
\text { G-1 plus } \\
\text { G-2 plus }\end{array}$ & SAGE 1-STEP (Origio) & $\begin{array}{l}\text { ICSI } \\
\text { Fresh }\end{array}$ & & & $x$ & $x$ & & $x$ & $x$ & & \\
\hline $\begin{array}{l}\text { Gu } \\
\text { et al., } \\
2016\end{array}$ & $\begin{array}{l}\text { G5 } \\
\text { HAS solution }\end{array}$ & $\begin{array}{l}\text { Quinn's advantage } \\
\text { media (SAGE) }\end{array}$ & $\begin{array}{l}\text { IVF/ICSI } \\
\text { Fresh/frozen }\end{array}$ & & $x$ & & & & & & & \\
\hline $\begin{array}{l}\text { De Vos } \\
\text { et al., } \\
2015\end{array}$ & G5 & $\begin{array}{l}\text { Universal IVF Medium, } \\
\text { EmbryoAssist, and } \\
\text { BlastAssist (Medicult) }\end{array}$ & $\begin{array}{l}\text { IVF/ICSI } \\
\text { Fresh }\end{array}$ & & $x$ & & & & & & & \\
\hline $\begin{array}{l}\text { Lin } \\
\text { et al., } \\
2015\end{array}$ & G5 & Global (IVF Online) & $\begin{array}{l}\text { IVF/ICSI } \\
\text { Fresh }\end{array}$ & & & & & & $x$ & & & \\
\hline $\begin{array}{l}\text { Lin } \\
\text { et al., } \\
2013\end{array}$ & $\begin{array}{l}\text { G5 } \\
\text { HSA solution }\end{array}$ & $\begin{array}{l}\text { Quinn's advantage } \\
\text { media (SAGE) } \\
\text { and Global culture } \\
\text { medium (IVF online) }\end{array}$ & $\begin{array}{l}\text { IVF } \\
\text { Fresh }\end{array}$ & & $x$ & & & & $x$ & & & \\
\hline $\begin{array}{l}\text { Eskild } \\
\text { et al., } \\
2013\end{array}$ & $\begin{array}{l}\text { G-IVF Plus } \\
\text { G-1 Plus }\end{array}$ & $\begin{array}{l}\text { Universal IVF Medium } \\
\text { and ISM1 (Medicult) }\end{array}$ & $\begin{array}{l}\text { IVF/ICSI } \\
\text { Fresh }\end{array}$ & & $x$ & & & & & & & \\
\hline
\end{tabular}

LBR: live birth rate, BW: birthweight, FR: fertilization rate, IR: implantation rate, BPR: biochemical pregnancy rate, CPR: clinical pregnancy rate, MR: miscarriage rate, MP: multiple pregnancies, CM: congenital malformations.

\section{Congenital malformations}

Only one study reported on congenital malformations. In an RCT, no difference in numbers of congenital malformations was found comparing G5 and HTF media (Kleijkers et al., 2016) (Table 7).

\section{DISCUSSION}

Defining the best embryo culture media can be a challenge as there are many different outcomes to assess the quality of the culture media. However, it is commonly accepted that live birth rate is the preferable outcome to assess IVF/ICSI success rates (Mantikou et al., 2013). Kleijkers et al. (2016) is the only study that evaluated live birth rate comparing G5 to another media, and they found a slightly higher live birth rate for G5 compared to HTF media, however not significant. The study was designed to detect a difference of $10 \%$, but even a smaller difference may be of interest if this can be confirmed in more RCTs. The fact that only one of the studies included live birth rates (Kleijkers et al., 2016), which is considered the golden standard, clearly emphasizes the lack of RCTs reporting on live birth rate.

Some of the other studies had outcomes that approached live birth rates. Hambiliki et al. (2011) assessed delivery rate defined as the ratio between deliveries and embryos transferred. However, there are different guidelines for the numbers of embryos transferred per cycle. This makes comparison among centers difficult. Hassani et al. (2013) compared "baby take home rates" but gave no clear definition of the term. Future studies should adhere to the same definitions, and use live birth rate as the main outcome, so studies can be compared.

In this review, six of the eleven studies assessed birthweight with varying results. This is in line with previous studies, where some have shown that the type of culture media could influence birthweight (Dumoulin et al., 2010; 


\begin{tabular}{|c|c|c|c|c|c|c|c|c|}
\hline & 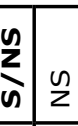 & $\begin{array}{l}n \\
z \\
n \\
\end{array}$ & $\sin z$ & $n$ & $n=$ & un & $\sum \Omega$ & us \\
\hline & 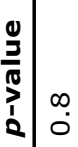 & \begin{tabular}{|l|} 
\\
$\frac{0}{\pi}$ \\
$\frac{\pi}{\pi}$ \\
1 \\
0
\end{tabular} \mid & 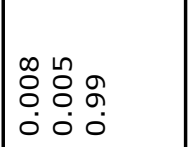 & $\begin{array}{l}\ddot{0} \\
0 \\
0\end{array}$ & 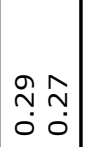 & \begin{tabular}{l}
\multirow{2}{0}{} \\
$\stackrel{0}{0}$ \\
0
\end{tabular} & $\mid \begin{array}{ll}\hat{n} & \hat{\sigma} \\
\tilde{n} & \tilde{m} \\
0 & 0 \\
0\end{array}$ & $\begin{array}{l}\stackrel{0}{0} \\
\tilde{O} \\
0 \\
0\end{array}$ \\
\hline & & $\begin{array}{l}\frac{ \pm}{z} \\
y \\
\alpha \\
\alpha\end{array}$ & & & & & 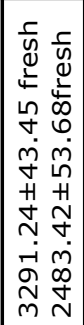 & 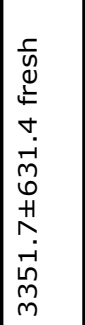 \\
\hline & 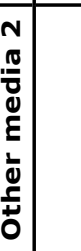 & 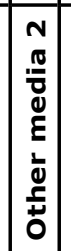 & & & & & 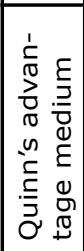 & $\sum_{\substack{n \\
-1}}^{-1}$ \\
\hline & 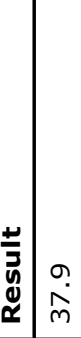 & 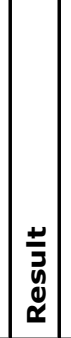 & 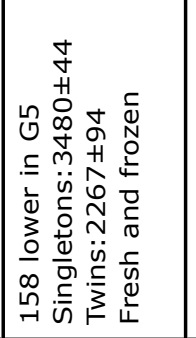 & $\begin{array}{l}\frac{c}{n} \\
\underline{d} \\
\stackrel{2}{2} \\
0 \\
0 \\
+1 \\
0 \\
m \\
0 \\
m\end{array}$ & 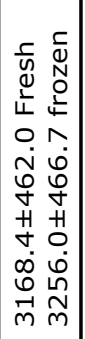 & 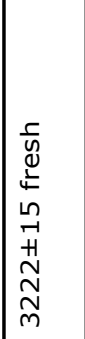 & 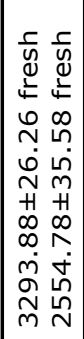 & 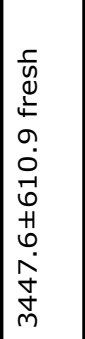 \\
\hline & 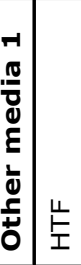 & 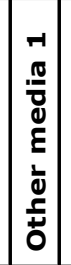 & $\begin{array}{l}\text { 屴 } \\
\text { I }\end{array}$ & 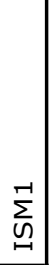 & 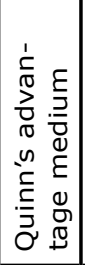 & 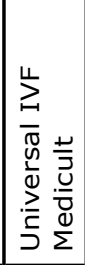 & $\begin{array}{l}\overline{0} \\
0 \\
0 \\
0\end{array}$ & 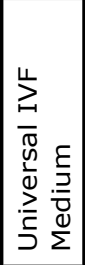 \\
\hline & 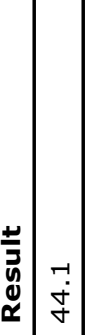 & 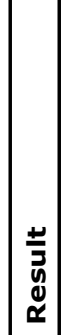 & 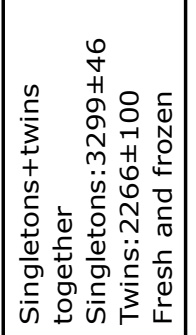 & 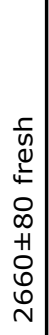 & 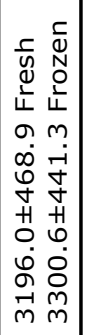 & 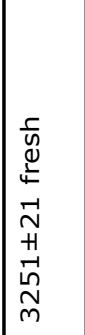 & 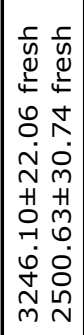 & 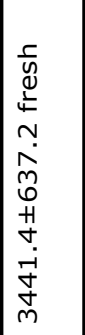 \\
\hline 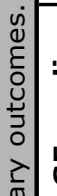 & 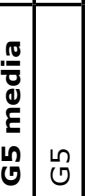 & 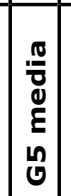 & $\begin{array}{l}n \\
0\end{array}$ & 号 & 帒 & 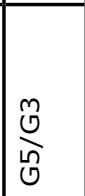 & $\begin{array}{l}\text { 足 } \\
\text { r }\end{array}$ & 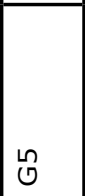 \\
\hline 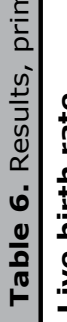 & 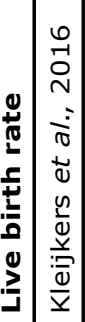 & 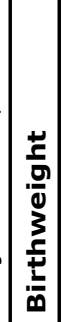 & 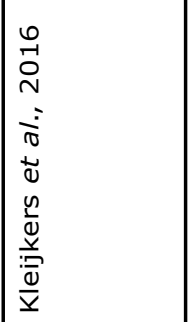 & 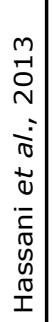 & 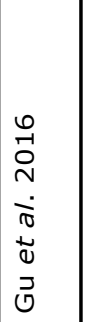 & $\begin{array}{l}* \\
\omega \\
0 \\
0 \\
N \\
\vdots \\
\vdots \\
0 \\
0 \\
n \\
0 \\
o \\
0 \\
0\end{array}$ & 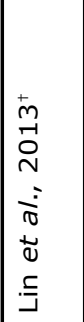 & 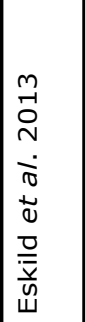 \\
\hline
\end{tabular}

Nelissen et al., 2012), other studies found no differences (Eaton et al., 2012; Vergouw et al., 2012). Birthweight is a popular outcome, but it is associated with several potentially confounding factors and it is complicated to interpret regarding the health of the child. On the contrary, larger birthweight might result in a higher risk of caesarian section, fetal hypoxia and stillbirth (Berntsen \& Pinborg, 2018) and there may be later health risks for the child (Pinborg, 2019).

As mentioned, altering epigenetics is believed to be a mechanism that may be influenced by different culture media, and therefore might influence birthweight and future health of the child (Kleijkers et al., 2015).

Some of the included studies assessed fresh embryo transfers only, while other studies assessed both fresh and frozen embryo transfers. Previous studies suggest the use of either fresh or frozen embryos could influence perinatal outcomes, and frozen embryo transfers might result in a higher birthweight than fresh embryo transfers (Wong et al., 2017; Berntsen \& Pinborg, 2018). This is supported by the results on birthweight from Gu et al. (2016); and therefore, birthweight should be related to whether the child was the result of fresh or frozen embryo transfer.

The comparison between G5 series and other culture media is complicated by the fact that the Vitrolife G5 series consists of more than ten products according to their brochure (A link to the list of Vitrolife G5 products can be found in the references). Even inside the G5 series, there are different options for embryo culture media: G-1 Plus and G-2 Plus are ready for use, while addition of human serum albumin is needed in the equivalent G-1 and G-2. Previous studies suggest that these two options of protein sources inside the $\mathrm{G} 5$ series might result in a difference in birthweight (Zhu et al., 2014).

There were no significant findings in fertilization rate, biochemical pregnancy rates, miscarriage rates, multiple pregnancy rates and congenital malformations. The secondary outcomes must be interpreted with care regarding the quality of embryo culture media. Like birthweight, they become relevant if there is a clear correlation to IVF success rates, such as measured in live birth rates or child's health.

While some of the media are sequential (G5 (Vitrolife), Sequential media (Cook), ISM1 (Medicult) and Quinn's advantage media (SAGE), others are continuous/single media (HTF (Irvine Scientifics), GL BLAST sole medium, Universal IVF Medium (Medicult), SAGE 1-step (Origio) and Global (IVF online). No difference was found between single versus sequential media, which is in line with results from systematic reviews on this aspect (Sfontouris et al., 2016; Dieamant et al., 2017).

In general, the comparison of the studies is difficult since there are varying definitions of inclusion criteria for women, varying definitions of outcomes and varying laboratory routines. For instance, different guidelines for transferring one or more embryos at a time could influence some of the outcomes and may increase live birth rates. Most of the studies did not report on dropouts. It is unclear whether there were no dropouts or if they did not include them in their analyses and this might cause bias. In one retrospective cohort study (Lin et al., 2013), there were no clear descriptions of when they used one culture media or the other. If the distribution of the culture media is not random, this might cause selection biases. Only one study (Kleijkers et al., 2016) described a proper blinding in their methods. The lack of good description of the randomization between the culture media might be a problem. While some of the outcomes such as the biochemical pregnancy rates are measurable facts, there is a considerable subjectivity in the assessment of the best embryo for transfer. 


\begin{tabular}{|c|c|c|c|c|c|c|c|c|}
\hline $\begin{array}{l}\text { Fertilization } \\
\text { rate }\end{array}$ & $\begin{array}{c}\text { G5 } \\
\text { media }\end{array}$ & Result & Other media 1 & Result & $\begin{array}{l}\text { Other } \\
\text { media } 2\end{array}$ & Result & $p$ & $\begin{array}{l}\text { S/ } \\
\text { NS }\end{array}$ \\
\hline $\begin{array}{l}\text { Kleijkers } \\
\text { et al., } \\
2016\end{array}$ & G5 & 62.9 & HTF & 69.1 & & & $<0.001$ & $\mathrm{~S}$ \\
\hline $\begin{array}{l}\text { Zhang } \\
\text { et al., } \\
2016\end{array}$ & G5 & 71.3 & $\begin{array}{l}\text { Cook sequential } \\
\text { medium }\end{array}$ & 71.0 & & & $>0.05$ & NS \\
\hline $\begin{array}{l}\text { Ceschin } \\
\text { et al., } \\
2016\end{array}$ & G5 & 67 & GV BLAST sole & 67 & & & 0.59 & NS \\
\hline $\begin{array}{l}\text { Hambiliki } \\
\text { et al., } \\
2011\end{array}$ & G5 & 73.5 & Universal IVF Medium & 67.2 & & & 0.030 & $\mathrm{~S}$ \\
\hline $\begin{array}{l}\text { Lopéz-Pelayo } \\
\text { et al., } \\
2018\end{array}$ & G5 & 69.11 & SAGE 1-STEP & 70.07 & & & 0.736 & NS \\
\hline $\begin{array}{l}\text { Implantation } \\
\text { rate }\end{array}$ & $\begin{array}{c}\text { G5 } \\
\text { media }\end{array}$ & Result & Other media 1 & Result & $\begin{array}{l}\text { Other media } \\
2\end{array}$ & Result & $\boldsymbol{p}$ & $\begin{array}{l}\text { S/ } \\
\text { NS }\end{array}$ \\
\hline $\begin{array}{l}\text { Kleijkers } \\
\text { et al., } \\
2016\end{array}$ & G5 & 20.2 fresh & HTF & $\begin{array}{l}15.3 \\
\text { fresh }\end{array}$ & & & $<0.001$ & $\mathrm{~S}$ \\
\hline $\begin{array}{l}\text { Zhang } \\
\text { et al., } \\
2016\end{array}$ & G5 & 29.0 & $\begin{array}{l}\text { Cook sequential } \\
\text { medium }\end{array}$ & 30.3 & & & $>0.05$ & NS \\
\hline $\begin{array}{l}\text { Hassani } \\
\text { et al., } \\
2013\end{array}$ & G5 & 12 & ISM1 & 15 & & & 0.16 & NS \\
\hline $\begin{array}{l}\text { Hambiliki } \\
\text { et al., } \\
2011\end{array}$ & G5 & 40.9 & Universal IVF Medium & 37.5 & & & 0.818 & NS \\
\hline $\begin{array}{l}\text { Lopéz-Pelayo } \\
\text { et al., } \\
2018 \\
\end{array}$ & G5 & 25.57 & SAGE 1-STEP & 30.16 & & & 0.520 & NS \\
\hline $\begin{array}{l}\text { Biochemical } \\
\text { pregnancy } \\
\text { rate }\end{array}$ & $\begin{array}{c}\text { G5 } \\
\text { media }\end{array}$ & Result & Other media 1 & Result & $\begin{array}{l}\text { Other media } \\
2\end{array}$ & Result & $\boldsymbol{p}$ & $\begin{array}{l}\text { S/ } \\
\text { NS }\end{array}$ \\
\hline $\begin{array}{l}\text { Kleijkers } \\
\text { et al., } \\
2016\end{array}$ & G5 & 56.6 & HTF & 50.1 & & & 0.06 & NS \\
\hline $\begin{array}{l}\text { Ceschin } \\
\text { et al., } \\
2016\end{array}$ & G5 & 41.17 & GV BLAST sole & 38.46 & & & 0.83 & NS \\
\hline $\begin{array}{l}\text { Hambiliki } \\
\text { et al., } \\
2011\end{array}$ & G5 & 49.3 & $\begin{array}{c}\text { Universal IVF } \\
\text { medium/EmbryoAssist }\end{array}$ & 50.0 & & & 1.00 & NS \\
\hline $\begin{array}{l}\text { Clinical } \\
\text { pregnancy } \\
\text { rate }\end{array}$ & $\begin{array}{c}\text { G5 } \\
\text { media }\end{array}$ & Result & Other media 1 & Result & $\begin{array}{l}\text { Other media } \\
2\end{array}$ & Result & $\boldsymbol{p}$ & $\begin{array}{l}\text { S/ } \\
\text { NS }\end{array}$ \\
\hline $\begin{array}{l}\text { Kleijkers } \\
\text { et al., } \\
2016\end{array}$ & G5 & 47.7 & HTF & 40.1 & & & 0.03 & $\mathrm{~S}$ \\
\hline $\begin{array}{l}\text { Zhang } \\
\text { et al., } \\
2016\end{array}$ & G5 & 50.0 & Cook sequential media & 46.7 & & & $>0.05$ & NS \\
\hline $\begin{array}{l}\text { Hassani } \\
\text { et al., } \\
2013\end{array}$ & G5 & 27.6 & ISM1 & 32.1 & & & 0.23 & NS \\
\hline
\end{tabular}




\begin{tabular}{|c|c|c|c|c|c|c|c|c|}
\hline $\begin{array}{l}\text { Hambiliki } \\
\text { et al., } \\
2011\end{array}$ & G5 & 46.4 & Universal IVF Medium & 36.4 & & & 0.467 & NS \\
\hline $\begin{array}{l}\text { Lopéz-Pelayo } \\
\text { et al., } \\
2018^{*}\end{array}$ & G5 & $\begin{array}{l}41.05 \\
(37.7)\end{array}$ & SAGE 1-STEP & $\begin{array}{c}55.88 \\
(49.60)\end{array}$ & & & $\begin{array}{c}0.213 \\
(0.357)\end{array}$ & NS \\
\hline $\begin{array}{l}\text { Lin } \\
\text { et al., } \\
2015^{+} \\
\end{array}$ & G5 & 44.43 & G5 Plus & 43.34 & Global & 41.25 & & S \\
\hline $\begin{array}{l}\text { Lin } \\
\text { et al., } \\
2013\end{array}$ & G5 & 42.9 & Global & 40.8 & $\begin{array}{c}\text { Quinn's } \\
\text { advantage } \\
\text { medium }\end{array}$ & 39.3 & & NS \\
\hline $\begin{array}{l}\text { Miscarriage } \\
\text { rate }\end{array}$ & $\begin{array}{c}\text { G5 } \\
\text { media }\end{array}$ & Result & Other media 1 & Result & $\begin{array}{c}\text { Other media } \\
2 \\
\end{array}$ & Result & $\boldsymbol{p}$ & $\begin{array}{l}\text { S/ } \\
\text { NS }\end{array}$ \\
\hline $\begin{array}{l}\text { Kleijkers } \\
\text { et al., } \\
2016 \\
\end{array}$ & G5 & 15.8 & HTF & 13.4 & & & 0.33 & NS \\
\hline $\begin{array}{l}\text { Hassani } \\
\text { et al., } \\
2013\end{array}$ & G5 & 21.1 & ISM1 & 20.5 & & & 0.9 & NS \\
\hline $\begin{array}{l}\text { Lopéz-Pelayo } \\
\text { et al., } \\
2018^{*}\end{array}$ & G5 & $\begin{array}{l}9.52 \\
(9.61)\end{array}$ & SAGE 1-STEP & $\begin{array}{c}14.29 \\
(16.90)\end{array}$ & & & $\begin{array}{c}0.472 \\
(0.266)\end{array}$ & NS \\
\hline $\begin{array}{l}\text { Multiple } \\
\text { Pregnancy } \\
\text { rate }\end{array}$ & $\begin{array}{c}\text { G5 } \\
\text { media }\end{array}$ & Result & Other media 1 & Result & $\begin{array}{c}\text { Other media } \\
2\end{array}$ & Result & $\boldsymbol{p}$ & $\begin{array}{l}\text { S/ } \\
\text { NS }\end{array}$ \\
\hline $\begin{array}{l}\text { Kleijkers } \\
\text { et al., } \\
2016\end{array}$ & G5 & 10.3 & HTF & 13.2 & & & 0.40 & NS \\
\hline $\begin{array}{l}\text { Hassani } \\
\text { et al., } \\
2013\end{array}$ & G5 & 3.8 & ISM1 & 8.5 & & & 0.19 & NS \\
\hline $\begin{array}{l}\text { Congenital } \\
\text { malformations }\end{array}$ & $\begin{array}{c}\text { G5 } \\
\text { media }\end{array}$ & Result & Other media 1 & Result & $\begin{array}{c}\text { Other media } \\
2\end{array}$ & Result & $p$ & $\begin{array}{l}\text { S/ } \\
\text { NS }\end{array}$ \\
\hline $\begin{array}{l}\text { Kleijkers } \\
\text { et al., } \\
2016\end{array}$ & G5 & $\begin{array}{l}\text { Single- } \\
\text { tons: } \\
\text { 2.5 Major } \\
\text { 3.7 Minor } \\
\text { Twins: } \\
\text { 2.6 Major } \\
\text { 2.6 Minor }\end{array}$ & HTF & $\begin{array}{c}\text { Single- } \\
\text { tons: } \\
\text { Major } \\
4.4 \\
\text { Minor } \\
4.4 \\
\text { Twins: } \\
4.8 \mathrm{Ma}- \\
\text { jor } \\
0.0 \mathrm{Mi}- \\
\text { nor }\end{array}$ & & & $\begin{array}{l}0.52 \\
0.78 \\
1.00 \\
0.48\end{array}$ & $\begin{array}{l}\text { Over- } \\
\text { all NS }\end{array}$ \\
\hline
\end{tabular}

All results are measured in percentages.

*Without brackets: Fresh. In brackets: Numbers for cumulative fresh and frozen ICSI.

${ }^{+}$G5 and G5 Plus compared to Global. Significantly higher clinical pregnancy rates in the G5 and G5 Plus group compared to the Global group.

There are some limitations to this review. There were five RCTs and six retrospective cohort studies. Only one RCT had a description of a good design including blinding of both patients and doctors, proper description and handling of dropouts and a power calculation. The other studies had varying data quality due to the description of the population, the randomization, handling of dropouts etc. Most studies randomized women, whereas in two studies the oocytes were randomized. As long as the randomization is done properly (and blinded), and the study has a reasonable size, this will most likely not influence the results. G5 media is compared to different culture media, which means that there are only few results examining some of the same outcomes (Table 6 and 7). The results of this review are based on comparing the results of the individual studies. Since the culture media, the inclusion criteria for the women and the definitions of the outcome vary in the studies; it was not possible to do a metanalysis on the topic.

As mentioned, there are many culture media available and many different outcomes, and so far there is very limited good evidence when comparing different culture media. This review indicates that no culture media is clearly superior or inferior to others, which allows the embryologist to take other factors such as affordability, availability, workload in the laboratory and experience/preference into account when choosing a media. Furthermore, the different 
outcomes highlight the importance of further research into media effects, both on success rates and on the long-term health issues, where evidence hopefully becomes available during the next years.

\section{CONCLUSION}

In conclusion, Vitrolife G5 series culture media was found to have a trend towards higher live birth rates, but not significant compared to other common culture media. This result is comprised of only one trial (RCT).

Birthweight had equivocal results with three out of six studies showing significantly lower (2)/higher (1) birthweights, whereas the others were non-significant. Likewise, overall no significant differences were found concerning the secondary outcomes.

More RCTs are needed, with uniform definitions of outcomes. There is a lack of studies reporting on live birth rate. Most importantly, an effort should be made to assess culture media regarding the effect on short-term and longterm health of the IVF children.

\section{CONFLICT OF INTERESTS}

None.

\author{
Corresponding Author \\ Lena Bick \\ Faculty of Health, \\ Aarhus University \\ Nordre Ringgade 1 \\ 8000 Aarhus, Denmark \\ E-mail: lenab5000@gmail.com
}

\section{REFERENCES}

Berntsen S, Pinborg A. Large for gestational age and macrosomia in singletons born after frozen/thawed embryo transfer (FET) in assisted reproductive technology (ART). Birth Defects Res. 2018;110:630-43. PMID: 29714057 DOI: $10.1002 / b d r 2.1219$

Ceschin II, Ribas MH, Ceschin AP, Nishikawa L, Rocha CC, Pic-Taylor A, Baroneza JE. A prospective randomized study comparing two commercially available types of human embryo culture media: G1-PLUS ${ }^{\mathrm{TM}} / \mathrm{G} 2-$ PLUS $^{\mathrm{TM}}$ sequential medium (Vitrolife) and the GL BLAST ${ }^{\mathrm{TM}}$ sole medium (Ingamed). JBRA Assist Reprod. 2016;20:23-6. PMID: 27203302 DOI: $10.5935 / 1518-0557.20160006$

Chronopoulou E, Harper JC. IVF culture media: past, present and future. Hum Reprod Update. 2015;21:39-55. PMID: 25035437 DOI: 10.1093/humupd/dmu040

De Vos A, Janssens $R$, Van de Velde $H$, Haentjens $P$, Bonduelle $M$, Tournaye $H$, Verheyen $G$. The type of culture medium and the duration of in vitro culture do not influence birthweight of ART singletons. Hum Reprod. 2015;30:207. PMID: 25406185 DOI: 10.1093/humrep/deu286

Dieamant F, Petersen CG, Mauri AL, Comar V, Mattila M, Vagnini LD, Renzi A, Petersen B, Ricci J, Oliveira JB, Baruffi $R L$, Franco Junior JG. Single versus sequential culture medium: which is better at improving ongoing pregnancy rates? A systematic review and meta-analysis. JBRA Assist Reprod. 2017;21:240-6. PMID: 28837034 DOI: 10.5935/1518-0557.20170045
Dumoulin JC, Land JA, Van Montfoort AP, Nelissen EC, Coonen E, Derhaag JG, Schreurs IL, Dunselman GA, Kester $A D$, Geraedts JP, Evers JL. Efeito da cultura in vitro de embriões humanos no peso ao nascer de recém-nascidos. Hum Reprod. 2010; 25: 605-12. PMID: 20085915 DOI: 10.1093/humrep/dep456

Eaton JL, Lieberman ES, Stearns C, Chinchilla M, Racowsky C. Embryo culture media and neonatal birthweight after IVF. Hum Reprod. 2012; 27: 375-9. PMID: 22128298 DOI: 10.1093/humrep/der381

Eskild A, Monkerud L, Tanbo T. Peso ao nascer e peso da placenta; fazer mudanças nos meios de cultura usados para fertilização in vitro? Comparações com gravidezes espontâneas nos períodos de tempo correspondentes. Hum Reprod. 2013; 28: 3207-14. PMID: 24108218 DOI: $10.1093 /$ humrep/det376

Gu F, Deng M, Gao J, Wang Z, Ding C, Xu Y, Zhou C. Os efeitos dos meios de cultura de embriões no peso ao nascer de bebês únicos por meio de transferência de embriões frescos ou congelados: um estudo retrospectivo em grande escala. BMC Pregnancy Childbirth. 2016; 16:270. PMID: 27643856 DOI: $10.1186 / s 12884-016-1077-7$

Hambiliki F, Sandell P, Yaldir F, Stavreus-Evers A. Um estudo prospectivo randomizado de oócitos irmãos de dois sistemas de mídia para a cultura de embriões em estágio de clivagem - impacto na taxa de fertilização. J Assist Reprod Genet. 2011; 28: 335-41. DOI: 10.1007/s10815010-9518-0

Hassani F, Eftekhari-Yazdi P, Karimian L, Valojerdi MR, Movaghar B, Fazel M, Fouladi HR, Shabani F, Johansson L. Os efeitos do meio ISM1 na qualidade do embrião e nos resultados dos ciclos de FIV / ICSI. Int J Fertil Steril. 2013; 7: 108-15. PMID: 24520472

Kleijkers SH, Eijssen LM, Coonen E, Derhaag JG, Mantikou E, Jonker MJ, Mastenbroek S, Repping S, Evers JL, Dumoulin JC, Van Montfoort AP. Differences in gene expression profiles between human preimplantation embryos cultured in two different IVF culture media. Hum Reprod. 2015;30:230311. PMID: 26202924 DOI: 10.1093/humrep/dev179

Kleijkers SH, Mantikou E, Slappendel E, Consten D, Van Echten-Arends J, Wetzels AM, Van Wely M, Smits LJ, Van Montfoort AP, Repping S, Dumoulin JC, Mastenbroek S. Influence of embryo culture medium (G5 and HTF) on pregnancy and perinatal outcome after IVF: a multicenter RCT. Hum Reprod. 2016;31:2219-30. PMID: 27554441 DOI: $10.1093 /$ humrep/dew156

Lin S, Li M, Lian Y, Chen L, Liu P. No effect of embryo culture media on birthweight and length of newborns. Hum Reprod. 2013;28:1762-7. PMID: 23595972 DOI: 10.1093/ humrep/det095

Lin S, Li R, Zheng X, Chi H, Ren X, Yang R, Liu P, Qiao J. Influence of embryo culture medium on incidence of ectopic pregnancy in in vitro fertilization. Fertil Steril. 2015;104:1442-5. PMID: 26385404 DOI: 10.1016/j. fertnstert.2015.08.029 
López-Pelayo I, Gutiérrez-Romero JM, Armada AI, CaleroRuiz MM, Acevedo-Yagüe PJ. Comparison of two commercial embryo culture media (SAGE-1 step single medium vs. G1-PLUSTM/G2-PLUSTM sequential media): influence on in vitro fertilization outcomes and human embryo quality. JBRA Assist Reprod. 2018;22:128-33. PMID: 29697926 DOI: $10.5935 / 1518-0557.20180024$

Mantikou E, Youssef MA, Van Wely M, Van Der Veen F, Al-Inany HG, Repping S, Mastenbroek S. Embryo culture media and IVF/ICSI success rates: a systematic review. Hum Reprod Update. 2013;19:210-20. PMID: 23385469 DOI: $10.1093 /$ humupd/dms061

Nelissen EC, Van Montfoort AP, Coonen E, Derhaag JG, Geraedts JP, Smits LJ, Land JA, Evers JL, Dumoulin JC. Further evidence that culture media affect perinatal outcome: findings after transfer of fresh and cryopreserved embryos. Hum Reprod. 2012;27:1966-76. PMID: 22552689 DOI: 10.1093/humrep/des145

Pinborg A. Short- and long-term outcomes in children born after assisted reproductive technology. BJOG. 2019;126:145-8. PMID: 30120870 DOI: 10.1111/14710528.15437

Schwarzer C, Esteves TC, Araúzo-Bravo MJ, Le Gac S, Nordhoff V, Schlatt S, Boiani M. ART culture conditions change the probability of mouse embryo gestation through defined cellular and molecular responses. Hum Reprod. 2012;27:2627-40. PMID: 22736328 DOI: 10.1093/ humrep/des 223
Sfontouris IA, Martins WP, Nastri CO, Viana IG, Navarro PA, Raine-Fenning N, Van Der Poel S, Rienzi L, Racowsky C. Blastocyst culture using single versus sequential media in clinical IVF: a systematic review and meta-analysis of randomized controlled trials. J Assist Reprod Genet. 2016;33:1261-72. PMID: 27491772 DOI: 10.1007/ s10815-016-0774-5

Vergouw CG, Kostelijk EH, Doejaaren E, Hompes PG, Lambalk CB, Schats R. The influence of the type of embryo culture medium on neonatal birthweight after single embryo transfer in IVF. Hum Reprod. 2012;27:2619-26. PMID: 22791752 DOI: 10.1093/humrep/des252

Wong KM, Van Wely M, Mol F, Repping S, Mastenbroek S. Fresh versus frozen embryo transfers in assisted reproduction. Cochrane Database Syst Rev. 2017;3:CD011184. PMID: 28349510 DOI: $10.1002 / 14651858 . C D 011184$.pub2

Youssef MM, Mantikou E, Van Wely M, Van Der Veen F, Al-Inany HG, Repping S, Mastenbroek S. Culture media for human pre-implantation embryos in assisted reproductive technology cycles. Cochrane Database Syst Rev. 2015;11:CD007876. PMID: 26585317 DOI: 10.1002/14651858.CD007876.pub2

Zhang $\mathrm{H}$, Zheng $\mathrm{Y}, \mathrm{Wu} \mathrm{Y}$, Ye D, Huang $\mathrm{X}$. A prospective randomized comparison of early embryo cleavage kinetics between two media culture systems. Pak J Med Sci. 2016;32:1375-9. PMID: 28083029 DOI: 10.12669/ pjms.326.10809

Zhu J, Li M, Chen L, Liu P, Qiao J. The protein source in embryo culture media influences birthweight: a comparative study between $\mathrm{G} 1 \mathrm{v} 5$ and G1-PLUS $\mathrm{v} 5$. Hum Reprod. 2014;29:1387-92. PMID: 24812314 DOI: 10.1093/humrep/deu103 


\section{Supplements}

Websites:

Link to the list of Vitrolife G5 products (last assessed April 15, 2020): http://www.evolutionvision.co.in/downloads/g5.pdf

Pico model

\begin{tabular}{|c|c|c|c|c|}
\hline & Description & Search terms & $\begin{array}{l}\text { PubMed and } \\
\text { Cochrane mesh } \\
\text { terms }\end{array}$ & $\begin{array}{l}\text { Embase Emtree } \\
\text { terms }\end{array}$ \\
\hline Population & $\begin{array}{l}\text { Infertile women } \\
\text { attending IVF }\end{array}$ & $\begin{array}{l}\text { IVF, in vitro } \\
\text { fertilization, } \\
\text { infertility, ART, } \\
\text { assisted reproductive } \\
\text { technology }\end{array}$ & $\begin{array}{l}\text { "Fertilization in } \\
\text { vitro", "infertility", } \\
\text { "Reproductive } \\
\text { Techniques, Assisted" }\end{array}$ & $\begin{array}{l}\text { "In vitro fertilization", } \\
\text { "infertility", "infertility } \\
\text { therapy" }\end{array}$ \\
\hline Indicator & $\begin{array}{l}\text { Influence of culture } \\
\text { media }\end{array}$ & $\begin{array}{l}\text { Culture media, culture } \\
\text { medium, culture } \\
\text { system, embryo } \\
\text { culture }\end{array}$ & "Culture media" & "Culture medium" \\
\hline Comparison & $\begin{array}{l}\text { Vitrolife G5 medium } \\
\text { compared to other } \\
\text { media }\end{array}$ & $\begin{array}{l}\text { Vitrolife, G5, v5, G-1, } \\
\text { G-2, G1, G2 }\end{array}$ & & \\
\hline Outcome & $\begin{array}{l}\text { Primary: live birth rate } \\
\text { (LBR), birth weight } \\
\text { (BW) } \\
\text { Secondary: } \\
\text { fertilization rate, } \\
\text { implantation } \\
\text { rate, biochemical } \\
\text { pregnancy rate, } \\
\text { clinical pregnancy } \\
\text { rate, miscarriage rate, } \\
\text { multiple pregnancy } \\
\text { rate, congenital } \\
\text { malformations }\end{array}$ & $\begin{array}{l}\text { Live birth rate, birth } \\
\text { rate, birth weight, } \\
\text { birthweight } \\
\text { Fertilization rate, } \\
\text { implantation } \\
\text { rate, biochemical } \\
\text { pregnancy rate, } \\
\text { clinical pregnancy } \\
\text { rate, pregnancy } \\
\text { rate, miscarriages, } \\
\text { abortions, multiple } \\
\text { pregnancies, } \\
\text { congenital } \\
\text { malformations, } \\
\text { congenital } \\
\text { abnormalities }\end{array}$ & $\begin{array}{l}\text { "Birth rate", "birth } \\
\text { weight" } \\
\text { "Pregnancy outcome", } \\
\text { "pregnancy, } \\
\text { multiple, "congenital } \\
\text { abnormalities" }\end{array}$ & $\begin{array}{l}\text { Birth rate, birth } \\
\text { weight } \\
\text { Multiple pregnancy, } \\
\text { pregnancy outcome, }\end{array}$ \\
\hline
\end{tabular}

\section{Searches}

Pubmed search

First, the search terms were divided into PICO search blocks:

P: IVF OR in vitro fertilization OR infertility OR ART OR assisted reproductive technology OR "Fertilization in Vitro"[Mesh]) OR "Infertility"[Mesh] OR "Reproductive Techniques, Assisted"[Mesh]

I: Culture media OR culture medium OR culture system OR embryo culture OR "Culture Media"[Mesh]

C: Vitrolife OR G5 OR v5 OR G-1 OR G-2

O: Live birth rate OR birth rate OR birth weight OR birthweight OR Fertilization rate OR implantation rate OR biochemical pregnancy rate OR clinical pregnancy rate OR pregnancy rate OR miscarriages OR abortions OR multiple pregnancies OR congenital malformations OR congenital abnormalities OR "Birth Rate"[Mesh] OR "Birth Weight"[Mesh] OR "Pregnancy Outcome"[Mesh])OR "Pregnancy, Multiple"[Mesh] OR "Congenital Abnormalities"[Mesh]

The search blocks were then combined for the final search:

$((((()((()((($ IVF) OR in vitro fertilization) OR infertility) OR ART) OR assisted reproductive technology) OR "Fertilization in Vitro"[Mesh]) OR "Infertility"[Mesh]) OR "Reproductive Techniques, Assisted"[Mesh]))) AND (((((((Culture media) OR culture medium) OR culture system) OR embryo culture) OR "Culture Media"[Mesh] $))))$ AND (((((((Vitrolife) OR G5) OR v5) OR G-1) OR G-2))) ) AND $((((()(((()(((()(((($ Live birth rate) OR birth rate) OR birth weight) OR birthweight) OR Fertilization rate) OR implantation rate) OR biochemical pregnancy rate) OR clinical pregnancy rate) OR pregnancy rate) OR miscarriages) OR abortions) OR multiple pregnancies) OR congenital malformations) OR congenital abnormalities) OR "Birth Rate"[Mesh]) OR "Birth Weight"[Mesh]) OR "Pregnancy Outcome"[Mesh]) OR "Pregnancy, Multiple"[Mesh]) OR "Congenital Abnormalities"[Mesh])))))

\section{Embase search}

First, the search terms were divided into PICO search blocks:

P: IVF OR in vitro fertilization OR infertility OR ART OR assisted reproductive technology OR 'in vitro fertilization'/exp OR 'infertility'/exp OR 'infertility therapy'/exp

I: Culture media OR culture medium OR culture system OR embryo culture OR 'culture medium'/exp

C: Vitrolife OR G5 OR v5 OR G-1 OR G-2 
O: Live birth rate OR birth rate OR birth weight OR birthweight OR Fertilization rate OR implantation rate OR biochemical pregnancy rate OR clinical pregnancy rate OR pregnancy rate OR miscarriages OR abortions OR multiple pregnancies OR congenital malformations OR congenital abnormalities OR 'birth rate'/exp OR 'birth weight'/exp OR 'pregnancy outcome'/exp OR 'multiple pregnancy'/exp OR 'congenital malformation'/exp

The search blocks were then combined for the final search:

(( (ivf OR in) AND vitro AND fertilization OR infertility OR art OR assisted) AND reproductive AND technology OR 'in vitro fertilization'/exp OR 'infertility'/exp OR 'infertility therapy'/exp) AND ((()culture AND media OR culture) AND medium OR culture) AND system OR embryo) AND culture OR 'culture medium'/exp) AND (vitrolife OR g5 OR v5 OR 'g 1' OR 'g 2') AND $((((()(((($ live AND birth AND rate OR birth) AND rate OR birth) AND weight OR birthweight OR fertilization) AND rate OR implantation) AND rate OR biochemical) AND pregnancy AND rate OR clinical) AND pregnancy AND rate OR pregnancy) AND rate OR miscarriages OR abortions OR multiple) AND pregnancies OR congenital) AND malformations OR congenital) AND abnormalities OR 'birth rate'/exp OR 'birth weight'/exp OR 'pregnancy outcome'/exp OR 'multiple pregnancy'/exp OR 'congenital malformation'/exp)

\section{Cochrane}

We ran the Cochrane search with the same search terms and mesh terms as the PubMed search.

\section{Calculation of multiple pregnancy rate}

Calculation of multiple pregnancy rate for (Kleijkers et al., 2016):

A total of 383 live births were included: 165 singletons and 38 (17.8\%) twins in the G5 group and 138 singletons and 42 $(23.3 \%)$ twins in the HTF group. The multiple pregnancy rate was defined as the percentage of live births resulting in more than one child:

G5: $19 /(19+165)=10.3 \%$

HTF: $21 /(21+138)=13.2 \%$

The P-value was calculated to be 0.404 by using MEDCALC.

Link: https://www.medcalc.org/calc/comparison_of_proportions.php

\section{List of Vitrolife $\mathbf{G 5}$ products}

List of G5 products according to a Vitrolife G5 series brochure. Name of the paper:

"The G5 Series ${ }^{\mathrm{TM}}$. Optimizing embryo development in a protective in vitro environment"

The brochure can be found on the following website: http://www.evolutionvision.co.in/downloads/g5.pdf Products:

G-RINSE ${ }^{\mathrm{TM}}$

G-MOPS ${ }^{\text {TM }} /$ G-MOPS ${ }^{\text {TM }}$ PLUS

G-GAMETE ${ }^{\text {TM }}$

G-IVF ${ }^{T M} / G-I^{T} F^{T M}$ PLUS

$\mathrm{G}-1^{\mathrm{TM}} / \mathrm{G}-1^{\mathrm{TM}}$ PLUS

G-2 ${ }^{\text {TM }} / \mathrm{G}-2^{\text {TM }}$ PLUS

EmbryoGlue ${ }^{\circledR}$

G-PGD ${ }^{\text {TM }}$

HSA-solution ${ }^{\mathrm{TM}}$

G-MM ${ }^{\text {TM }}$

G-FreezeKit Blast ${ }^{\mathrm{TM}}$

G-ThawKit Blast ${ }^{T M}$ 